\title{
PLANTAR POESIA
}

\section{Cida Sepulveda}

Não há liberdade de criação se a gente faz concessões ao ambiente literário. Inclusive, o fazer diferente é uma armadilha para muita gente que tenta romper com a tradição, na presunção de inovar.

A inovação é resultado de um processo, às vezes, doloroso, no qual se busca uma linguagem própria. $\mathrm{O}$ artista não inventa nem o mundo, nem uma nova linguagem, mas sintetiza seu repertório linguístico e emocional, a partir da experimentação, da recombinação dos elementos culturais, artísticos e vivenciais que o caracterizam ser.

No mundo do consumo exagerado, o escritor, para quem a escrita é vital, sofre com a contradição arte versus comércio, afinal, um artista verdadeiro não é um vendedor.

O meio literário brasileiro está impregnado de gente que deseja aparecer a qualquer preço e, para isso, cria uma rede de relações na qual os pares se promovem mutuamente, se garantem espaços, prêmios, empregos, curadorias, colunas em jornal etc.

Essa realidade não é nova. Há inúmeros exemplos de escritores antigos e novos que sofreram com a precariedade de vida a quem se submeteram em busca de realização artística e profissional. Cruz e Souza, Nelson Rodrigues e Hilda Hilst são exemplos bem próximos dessa situação nada invejável.

Mas, se um ET chegar ao Brasil e ouvir falar dos grandes prêmios literários, da FLIP e outros eventos semelhantes que proliferam pelo país todo, vai pensar que estou delirando, vai dizer que o meu problema é recalque. Afinal, tanto glamour, tanta divulgação, tanto barulho, não deve ser à toa. 
Afinal, o Brasil é ou não um país de leitores? Ele se perguntará, agoniado.

A resposta fica para você, leitor.

O que posso afirmar, com conviç̧ão, é que um escritor que escreve por desejo, pelo desafio de mudar o mundo, ainda que nos limites da linguagem, depende de leitores críticos, gente que aprecia arte de fato.

O problema é que as escolas, do nível básico ao superior, não oferecem um ensino voltado para o pensamento e para a arte. Na sociedade de individualismo extremado, focada no consumo, valores humanos são trocados por produtos descartáveis. Não há espaço para o estético enquanto objeto ligado à transcendência, à contemplação e à reflexão.

Que catarse provoca um objeto ininteligível, construído pela obsessão do escritor pela diferenciação (que resulta em artificialismo)? Ou a narração fluída, de linguagem estilizada, mas sem profundidade psicológica, sem verossimilhança?

Pois são estes os livros que abundam nas prateleiras das grandes livrarias brasileiras, além dos clássicos e dos consagrados, frequentemente, pós-morte.

O poeta Manoel de Barros, em uma de suas cartas para mim, escreveu, sobre um livro que nem foi publicado, do qual alguns textos foram extraídos para a composição de outro Todo amor tem seu dia de punhal, o seguinte:

Cida: A primeira impressão: tão intimista, tão intimista, e tão belo! Tem muita poesia dentro das palavras. A poesia não te larga. Que bom. "As palavras adormecem antes das árvores". Você se voltou tão pra dentro aqui que só vejo a dor o ego. Esse Córtex é uma prosa tão intimista que você, com ela, só se comunicará bem com os poetas. Será que basta? E parabéns, a poesia que não desgruda da Cida, apesar da prosa. O livro é para quem dói e saiba ver as palavras. Tudo que vejo dentro de sua palavra é dor e essência de vida. Você é mais sábia do que eu pensava.

São palavras que valem muito mais do que um prêmio, porque são sinceras, livres de interesses outros senão a própria poesia. Palavras que tem força de ato, que me colocam uma responsabilidade maior: não trair a tradição que a poesia impinge a si mesma.

Dedicar-me à educação básica tem sido uma resposta à solidão poética. Na educação eu planto a semente. Os leitores hão de brotar. 